\title{
OPEN
}

\section{Publisher Correction: mTORC1 and mTORC2 Differentially Regulate Cell Fate Programs to Coordinate Osteoblastic Differentiation in Mesenchymal Stromal Cells}

\author{
Theres Schaub, Dennis Gürgen, Deborah Maus, Claudia Lange, Victor Tarabykin, \\ Duska Dragun \& Björn Hegner
}

Correction to: Scientific Reports https://doi.org/10.1038/s41598-019-56237-w, published online 27 December 2019

In the original version of this Article, Björn Hegner was incorrectly listed as the corresponding author. The correct corresponding author for this Article is Duska Dragun. Correspondence and request for materials should be addressed to duska.dragun@charite.de. This error has now been corrected in the HTML and PDF versions of the Article.

\begin{abstract}
(c) (i) Open Access This article is licensed under a Creative Commons Attribution 4.0 International Ey License, which permits use, sharing, adaptation, distribution and reproduction in any medium or format, as long as you give appropriate credit to the original author(s) and the source, provide a link to the Creative Commons license, and indicate if changes were made. The images or other third party material in this article are included in the article's Creative Commons license, unless indicated otherwise in a credit line to the material. If material is not included in the article's Creative Commons license and your intended use is not permitted by statutory regulation or exceeds the permitted use, you will need to obtain permission directly from the copyright holder. To view a copy of this license, visit http://creativecommons.org/licenses/by/4.0/.
\end{abstract}

(C) The Author(s) 2020 